\title{
Nursing care protocol for patients with a ventricular assist device
}

\author{
Protocolo de cuidados de enfermagem a pacientes com dispositivo de assistência ventricular \\ Protocolo de atención de enfermería a pacientes con dispositivo de asistencia ventricular
}

\section{Regimar Carla Machado', Purificación Gironés", Andressa Rodrigues de Souza"', Rita Simone Lopes Moreiralv ${ }^{\mathrm{I}}$, Camila Bomfim von Jakitschv ${ }^{\mathrm{v}}$, João Nelson Rodrigues Branco ${ }^{\mathrm{vI}}$ \\ ' Universidade Federal de São Carlos, Department of Nursing. São Carlos, São Paulo, Brazil. \\ "Hospital La Fe, Transplant services. Valencia, Spain. \\ III Faculdade de Taquaritinga, Nursing Department. Taquaritinga, São Paulo, Brazil. \\ Iv Universidade Federal de São Paulo, Multidisciplinary Residency, Cardiology Program. São Paulo, Brazil. \\ ${ }^{\vee}$ Hospital Santa Casa de São José dos Campos. São José dos Campos, São Paulo, Brazil. \\ ${ }^{v}$ Universidade Federal de São Paulo, Department of Surgeries. São Paulo, Brazil.}

\section{How to cite this article:}

Machado RC, Gironés P, Souza AR, Moreira RSL, von Jakitsch CB, Branco JNR. Nursing care protocol for patients with a ventricular assist device. Rev Bras Enferm [Internet]. 2017;70(2):335-41. DOI: http://dx.doi.org/10.1590/0034-7167-2016-0363

\section{Submission: 07-21-2016 Approval: 10-15-2016}

\begin{abstract}
Objective: to develop and validate a nursing care protocol for patients with a ventricular assist device (VAD). Method: descriptive study, with a quantitative approach, for an instrument's methodological validation. Three stages were conducted: development of the instrument; protocol content validation according to the Delphi technique, and agreement among experts and the scientific literature. Results: based on the content validation, a care protocol for patients with a VAD was created and assessed by Spanish experts. Of the 15 items evaluated by means of the content validity index (CVI), 10 presented solid evidence of validation, with Kappa ranging between 0.87 and 1. Conclusion: the method enabled the validation of interventions that will contribute to qualified and standardized care for patients with a VAD.
\end{abstract}

Descriptors: Heart Failure; Assisted Circulation; Validation Studies; Protocols; Nursing Care.

\section{RESUMO}

Objetivo: elaborar e validar um protocolo de cuidados de enfermagem a pacientes com dispositivo de assistência ventricular (DAV). Método: estudo descritivo, com abordagem quantitativa de validação metodológica de instrumento. Seguiram-se três etapas: elaboração do instrumento; validação do conteúdo do protocolo segundo a técnica de Delphi e concordância entre peritos e a literatura científica. Resultados: com base na validação do conteúdo, elaborou-se um protocolo referente aos cuidados a paciente em uso de DAV avaliado por peritos/juízes espanhóis. Dos 15 itens avaliados, por meio do Índice de Validade de Conteúdo (IVC), 10 deles apresentaram forte evidência de validação com Kappa que variaram de 0,87 a 1. Conclusão: o método permitiu validar intervenções que contribuirão para um cuidado qualificado e uniformizado a pacientes em uso de DAV.

Descritores: Insuficiência Cardíaca; Circulação Assistida; Estudos de Validação; Protocolos; Cuidados de Enfermagem.

\section{RESUMEN}

Objetivo: elaborar y validar un protocolo de atención de enfermería a pacientes con dispositivo de asistencia ventricular (DAV). Método: estudio descriptivo, con abordaje cuantitativo, de validación metodológica de instrumento. Se siguieron tres etapas: elaboración del instrumento; validación del contenido del protocolo según técnica de Delphi y concordancia entre expertos y la literatura científica. Resultados: en base a la validación del contenido, se elaboró un protocolo referido a la atención de pacientes en uso de DAV, evaluado por expertos/jueces españoles. De los 15 ítems evaluados, mediante el índice de Validez de Contenido (IVC), 10 de ellos presentaron fuerte evidencia de validación con Kappa, variando entre 0,87 y 1. Conclusión: el método permitió validar intervenciones que contribuirán a una atención calificada y uniforme a pacientes en uso de DAV. Descriptores: Insuficiencia Cardíaca; Circulación Asistida; Estudios de Validación; Protocolos; Atención de Enfermería.

\section{CORRESPONDING AUTHOR Regimar Carla Machado E-mail: regimarmachado@gmail.com}




\section{INTRODUCTION}

The changes brought about by the industrialization of society and urbanization processes have led to changes in eating habits, sedentary lifestyle, obesity, and smoking habits in the population. Such changes are responsible for the increased incidence of cardiovascular diseases. Two million new cases of heart failure (HF) are diagnosed every year in developed countries, w twenty-three million people are affected globally, representing a major public health problem ${ }^{(1-2)}$.

Heart failure is a progressive condition of the cardiac muscle with frequent situations of immunological, mechanical, neurohormonal, and ischemic disorders that may cause changes in the structure of the pericardium and cardiac endothelium ${ }^{(2)}$.

The literature classifies the types of HF in left and right. The left dysfunction presents reduced contractility of the left ventricle (LV) with subsequent reduction of the cardiac output and ejection fraction (EF). The right dysfunction presents no pulmonary edema and presence of signs of systemic congestion (jugular distension, hepatomegaly, ascites, lower limb edema) $)^{(2-3)}$.

Heart failure is caused by hypertension, ischemia (coronary artery disease), valvular dysfunction, and cardiomyopathies, such as Chagas, hyperthropic, idiopathic, restrictive, and alcoholic ones ${ }^{(1-2)}$. Hypertension and dilated cardiomyopathy are relevant factors in the evolution of HF. Ischemia is one of the most common causes of decompensated HF as it causes a reduction in the myocardial contractility ${ }^{(2)}$.

Patients with HF presenting hemodynamic instability require periodical hospitalizations in order to improve their clinical condition through the use of inotropic agents and mechanical circulatory support (MCS), such as ventricular assist devices (VADs) ${ }^{(4)}$.

There are different types of VADs, such as percutaneous VADs, which are indicated for short-term use and may be inserted in the laboratory through the use of catheters, as a strategy to stabilize patients with acute cardiogenic shock. Long-term VADs are those surgically implanted and designed to increase the lifespan and/or as a bridge for transplantation. Moreover, VADs may be used to support the deficit of the right ventricle, left ventricle, or both ${ }^{(4)}$.

The main function of VADs consists in ensuring an effective systemic perfusion, avoiding multiple organs dysfunction, providing improvement of the cardiac output and pulmonary edema, reducing the central venous pressure, and reducing the neurohormonal activity activated by the HF. They are characterized according to their use, subdivided in counterpulsation support (intra-aortic balloon pump) and parallel assist (artificial ventricles) $^{(5-6)}$.

Extracorporeal membrane oxygenation (ECMO) is a shortacting MCS system indicated for cardiogenic shock and respiratory failure when surgical or conventional therapeutic procedures, including the use of an intra-aortic balloon pump, are not successful. In addition to being more economical than other $\mathrm{VADs}^{(7)}$, it provides ventricular support and is effective as a "bridge" for heart transplantation.

The Levitronix CentriMag is another short-term ventricular assist device characterized by an extracorporeal pump presenting an engine, a console, a blood flow probe, and a circuit. Its main advantages include ease of use, excellent reliability, and low risk of thrombosis ${ }^{(8)}$.

Despite the existence of studies addressing topics related to the care of patients using ventricular assist devices, there is no standardization of such care. Thus, this study points out the possibility of developing a practical and systematized instrument based on the analysis of agreement among evaluators.

A care protocol for patients using ventricular assist devices primarily aims at preventing complications resulting from the use of the device, such as thromboembolism, bleeding, limb ischemia, and infections. The objective of this study was to develop and validate a nursing care protocol for patients with a ventricular assist device.

\section{METHOD}

\section{Ethical aspects}

The protocol was submitted to the Biomedical Research Ethics Committee of the Polytechnic Teaching Hospital La Fé, in Valencia, Spain. All participants signed a free and informed consent form.

\section{Study design, setting, and period}

A descriptive study, using a quantitative approach, was conducted for methodological validation of an instrument. Three methodological stages were followed: instrument development; protocol content validation according to the Delphi technique, and agreement among experts and the scientific literature.

The study was conducted in a teaching hospital in the city of Valencia, Spain, between November 2012 and April 2013.

\section{Sample and inclusion and exclusion criteria}

The sample of individuals that make up the board of experts for the present study consisted of nurses working in the intensive care services of the mentioned hospital. Inclusion criteria were: being a nurse with minimum practical experience of one year in the care of patients using a VAD. Convenience sampling was used. Thus, contact to and selection of the sample were performed by "snowball sampling", in which the subjects participating in the research indicated other subjects.

\section{Study protocol}

The Delphi technique was used to validate the content. This technique consists in collecting data, tabulating, and assessing a given theme by means of the opinion of experts in the area. This validation criterion consists in the convergent opinion of the experts and emphasizes the need for a consensus among the group of participants ${ }^{(9)}$.

Judging means evaluating, giving an opinion; transforming something into the object of a process or demand ${ }^{(10)}$. Validation consists in a subjective way of evaluation and keeps the concern of the experts in assessing the instrument in relation to the clarity of its items, ease of reading, understanding, and presentation of the variables ${ }^{(9-10)}$.

Validation through an examination board was used. It consists in a strategy based on the set of scientific knowledge of 
professionals for the development of products, material or not, in order to evaluate a given practical situation.

Searches in the scientific literature ${ }^{(4-8,11-16)}$ were conducted for the elaboration of the protocol and to carry out the discussion of the variables related to the patient using a ventricle assist device.

In the first stage of the Delphi, one of the Spanish researchers contacted, at her work place, nursing professionals of a university hospital in Valencia, Spain; in total, she provided the data collection instrument to 115 nurses that met the inclusion criteria, with concomitant clarification on the aims, filling, and purpose of the study, between November 2012 and January 2013. A deadline of 30 days was set for analysis and return of the instrument. At the end of the deadline, 42 experts returned the instrument duly completed. The work technique consisted in the individual filling of the form (instrument), with a space for suggestions and without the presence of the researchers in order to configure their noninterference in the answers.

The experts performed the assessment through the use of a Likert scale, with three levels to measure the judgments and decreasing values from 3 to 1 (relevant, moderately relevant, not relevant) to evaluate the relevance, comprehensiveness, and clarity of each item of the protocol.

Categories scoring 3 (relevant) in the Likert scale that had the evaluation approved in a favorable consensus of $75 \%$ were considered for the statistic treatment. This agreement index was based on other validation studies ${ }^{(9-10)}$.

After the analysis of the items, the protocol was reformulated and sent back to the experts; they had 30 more days, between March and April 2013, to return it. However, only 34 experts returned the reassessed protocol, consisting in the second stage of the Delphi.
Initially, the protocol presented 15 items of care to patients using a VAD. However, after the two Delphi stages, five items were excluded for being considered not relevant to the theme.

\section{Statistics and analysis of results}

Data were entered in an Excel spreadsheet, and the software SPSS 17.0 was used for calculation; a level of significance of $5 \%$ was applied and observed. Descriptive statistics (frequency, mean, median, and standard deviation) and the Kappa index were used to assess the level of coincidence among the evaluators and the consistency of the experts in relation to keeping or not certain items of the instrument.

The content validity index (CVI), consisting in the calculation of the number of evaluators that considered the item relevant by the total of evaluators, was conducted to measure the agreement of the experts regarding the representativeness of the items in relation to the approached content. The items that presented convergent opinions by the evaluators with the established level of significance (CVI > 0.75 and Kappa > 0.70) were considered relevant. The original protocol was made up of 15 items related to the care of patients using a VAD. After the evaluation, four items were excluded as they were considered not pertinent to the theme.

\section{RESULTS}

All the 42 experts that made up the first stage of Delphi were Spanish nursing professionals of a teaching hospital in the city of Valencia, consisting in 32 (69.5\%) women and 10 $(21.8 \%)$ men, with mean age of 43.6 years $(+8.7)$, of whom $4(8.7 \%)$ had a doctorate degree, $12(26.1 \%)$ had a master's degree, $6(13.0 \%)$ had studies presented in scientific events in the area of this study, 5 (10.9\%) had publications in journals, and $1(2.1 \%)$ had a master's thesis in the area of this study.

Table 1 - Items of the nursing care protocol to patients with a ventricular assist device considered valid by the experts/evaluators in the two Delphi stages, Valencia, Spain, 2013

\begin{tabular}{|c|c|c|c|c|c|c|c|c|}
\hline \multirow{2}{*}{ Variables } & \multicolumn{2}{|c|}{ Yes } & \multicolumn{2}{|c|}{ No } & \multicolumn{2}{|c|}{ Total } & \multirow{2}{*}{ Kappa } & \multirow{2}{*}{ CVI } \\
\hline & $\mathbf{n}$ & $\%$ & $\mathbf{n}$ & $\%$ & $\mathbf{n}$ & $\%$ & & \\
\hline Clarification of the patient in relation to the risk-benefit ratio of the device & 28 & 83.0 & 6 & 17 & 34 & 100.0 & 0.87 & 0.94 \\
\hline Equipment functionality monitoring & 31 & 89.4 & 3 & 10.6 & 34 & 100.0 & 1 & 1 \\
\hline Monitoring of $\mathrm{HR}, \mathrm{MAP}, \mathrm{RAP}, \mathrm{LAP}, \mathrm{CO}, \mathrm{HI}, \mathrm{SvO}_{2}$ & 27 & 78.7 & 7 & 21.3 & 34 & 100.0 & 0.80 & 0.89 \\
\hline Monitoring of pulse oximetry, urine output, temperature & 30 & 87.2 & 4 & 12.8 & 34 & 100.0 & 0.96 & 0.98 \\
\hline Use of pressure relief mattresses to prevent pressure ulcers & 31 & 89.4 & 3 & 10.6 & 34 & 100.0 & 1 & 1 \\
\hline $\begin{array}{l}\text { Maintenance of the patient in horizontal decubitus position and contraindication of } \\
\text { the changing of decubitus }\end{array}$ & 28 & 83.0 & 6 & 17.0 & 34 & 100.0 & 0.77 & 0.87 \\
\hline $\begin{array}{l}\text { Conducting laboratorial exams such as gasometry (arterial gas analysis), creatinine, urea, } \\
\text { lactate, sodium, potassium, magnesium: } 66 \text { hours }\end{array}$ & 29 & 85.1 & 5 & 14.9 & 34 & 100.0 & 0.92 & 0.91 \\
\hline $\begin{array}{l}\text { Collection of total proteins and albumin, control of bilirubin, liver enzymes and } \\
\text { amylase, fibrinogen and D-dimer: daily }\end{array}$ & 28 & 83.0 & 6 & 17.0 & 34 & 100.0 & 0.83 & 0.91 \\
\hline Collection of blood culture & 25 & 72.3 & 9 & 27.7 & 34 & 100.0 & 0.76 & 0.87 \\
\hline Administration of prophylactic antibiotic therapy during the seven first days & 28 & 83.0 & 6 & 17.0 & 34 & 100.0 & 0.80 & 0.89 \\
\hline $\begin{array}{l}\text { Collection of tracheal secretion culture and surgical wound culture: in case of presence of } \\
\text { secretion }\end{array}$ & 27 & 80.9 & 7 & 19.1 & 34 & 100.0 & 0.92 & 0.96 \\
\hline
\end{tabular}

Note: $H R=$ Heart rate; $M A P=$ Mean arterial pressure; $R A P=$ Right atrium pressure; $L A P=$ Left atrium pressure; $C O=C a r d i a c$ output; $H I=H$ Heart index; SvO = Venous oxygen saturation; $C V I=$ Content validity index 
Chart 1 - Nursing care protocol for patients with a ventricular assist device

\begin{tabular}{|c|c|}
\hline Action & Description \\
\hline $\begin{array}{l}\text { 1. Clarification of the patient in relation to the risk-benefit ratio } \\
\text { of the device }\end{array}$ & Aimed at providing humanized care and reducing patient anxiety \\
\hline 2. Equipment functionality monitoring & $\begin{array}{l}\text { Prevention of console-related problems. Prevention of possible } \\
\text { obstruction of the system. }\end{array}$ \\
\hline 3. Monitoring: $\mathrm{HR}, \mathrm{MAP}, \mathrm{RAP}, \mathrm{LAP}, \mathrm{CO}, \mathrm{HI}, \mathrm{SvO}_{2}$. & Aimed at obtaining appropriate monitoring and clinical compensation. \\
\hline 4. Monitoring of pulse oximetry, urine output, temperature. & Aimed at obtaining appropriate monitoring and clinical compensation. \\
\hline 5. Use of pressure relief mattresses to prevent pressure ulcers. & $\begin{array}{l}\text { Redistribute and soften the pressure of a body on a surface and } \\
\text { prevent skin injuries. }\end{array}$ \\
\hline $\begin{array}{l}\text { 6. Maintenance of the patient in horizontal decubitus position } \\
\text { and contraindication of changing of decubitus. }\end{array}$ & Avoid obstruction and/or rupture in the system used by the device. \\
\hline $\begin{array}{l}\text { 7. Assessment of laboratorial exams such as gasometry, creatinine, } \\
\text { urea, lactate, sodium, potassium, magnesium: } 66 \text { hours. }\end{array}$ & $\begin{array}{l}\text { Analyze the occurrence of adverse prognoses, such as renal and } \\
\text { respiratory changes and ineffective tissue perfusion. }\end{array}$ \\
\hline $\begin{array}{l}\text { 8. Collection of total proteins and albumin, control of bilirubin, } \\
\text { liver enzymes and amylase, fibrinogen and D-dimer: daily. }\end{array}$ & Analyze the occurrence of liver complications and coagulopathies. \\
\hline $\begin{array}{l}\text { 9. Administration of prophylactic antibiotic therapy during the } \\
\text { seven first days as prescribed. }\end{array}$ & Perform the prophylaxis of infections related to the surgical wound. \\
\hline $\begin{array}{l}\text { 10. Collection of tracheal secretion culture and surgical } \\
\text { wound culture: in case of presence of secretion. }\end{array}$ & $\begin{array}{l}\text { Identify microorganisms that cause infections in the surgical wound } \\
\text { for an appropriate antibiotic therapy, if necessary. }\end{array}$ \\
\hline
\end{tabular}

Note: $H R=$ Heart rate; $M A P=$ Mean arterial pressure; $R A P=$ Right atrium pressure; $L A P=$ Left atrium pressure; CO = Cardiac output; HI = Heart index; SvO = Venous oxygen saturation.

\section{DISCUSSION}

The Brazilian Ministry of Health affirms that protocols are recommendations systematically developed to support the management of a health problem in a specific clinical circumstance, preferably based on the best scientific data. These protocols are important tools for upgrades in the health area, being used to reduce the inappropriate variations in clinical practice ${ }^{(17)}$.

Therefore, the implementation of clinical protocols to meet specific demands is extremely necessary. The clinical protocol for patients using a VAD should be instituted immediately after the indication for implantation of the device to enable consistency in the care planning.

Patients with HF and hemodynamically unstable using a VAD are high-complexity, critical patients requiring clinical follow-up and systematic care. This follow-up should be performed by the whole multidisciplinary team, aiming at care integration.

Systematized care is based on the need of teamwork for proper patient care. The present study emphasizes that the nursing staff represents about $70 \%$ of the whole staff in the health area and its professional premise is to establish comprehensive care through the 24 hours of care at the bedside and out of the bed, in mechanisms of work shift scales and with assignments of tasks well established by the relevant legislation in the different work categories (nurses, nursing technicians, and nursing aides) ${ }^{(11)}$.

The complexity of the nursing care provided in an intensive care unit, the dynamicity, and the monitoring of information that determine and change the therapy proposed to patients require adequate and constant training of these professionals ${ }^{(11)}$. Therefore, this study emphasizes the importance of developing and validating care protocols for critical patients by using appropriate methodologies to this process.

After two rounds of the Delphi technique in the present study it was observed that the item referring to the clarification of the patients' doubts in relation to the risk-benefit ratio of the device was validated. Psychosocial factors related to the patients and their family result from an adequate guidance by the health professionals in relation to the procedures that will be conducted or in relation to the reason and importance of each procedure in order to prepare the patient to initiate the therapy. Thus, anxiety is reduced and humanized care is provided.

Regarding the monitoring of the functionality of a VAD, a high level of agreement was verified among the experts. This is certainly an imperative assessment, as it depicts the care with equipment, defects, or maladjustments in the monitor of the console of each device, and obstructed or collapsed catheters ${ }^{(12)}$. These factors may lead to malfunction or cause delay or discontinuance of the therapy.

In relation to the importance of the hemodynamic monitoring, $\mathrm{HR}, \mathrm{MAP}, \mathrm{CO}, \mathrm{SvO}_{2}$ and pulse oximetry are widely discussed data in the literature ${ }^{(4,6)}$ aiming at obtaining accurate data from critical patients using a VAD, corroborating the positive consensus of the experts in this study. However, the verification of the pulse, urine output, and temperature also presented favorable consensus among the experts. It is important to mention that the indication to monitor the physiological state of critical patients is an important fact for the achievement of a better regulation of the medical therapy and data on patients' evolution. 
The prevention of pressure ulcers in patients using a VAD requires that nurses have competence to assess the inherent conditions of these patients that predispose them to tissue lesions by pressure, such as immobility, coronary disease, arterial hypertension, vasculopathies, and use of antibiotic therapy, as well as in the implementation of measures to prevent them ${ }^{(13)}$. Thus, the use of pressure relief mattresses presented a high index of agreement and acceptance among the experts of the protocol developed in this study. Water, air, or special gels are among the fluids used in such applications. Also, there are models that use alternating pressure between the body and the mattress through the insufflation and disinflation of compressed air in pneumatic pockets ${ }^{(14)}$.

The use of pressure relief mattresses is suggested to redistribute and soften the pressure of the body on a given surface, as well as to prevent skin lesions and ensure a more comfortable support of the body ${ }^{(13)}$, especially in relation to the relevance of an alternative method to prevent pressure ulcers, as the change of decubitus (consisting in the main approach adopted for this purpose) is contraindicated for patients using a VAD. These patients should remain in horizontal decubitus as decubitus change may generate complications for them, such as rupture or obstruction of the device, hemolysis, bleeding, thrombocytopenia, and arterial or venous thrombosis ${ }^{(15)}$.

Laboratory analysis of exams such as arterial blood gas analysis and evaluation of creatinine, urea, lactate, sodium, potassium, and magnesium indices at intervals of 6 hours also presented favorable indication in the protocol. Hyponatremia and impaired kidney function are adverse prognostic predictors in HF. Impaired kidney function may occur due to several reasons: comorbidities (diabetes mellitus, systemic arterial hypertension), cardiac output reduced by heart disease, or as an effect of the treatment (use of diuretics, angiotensin II converting enzyme inhibitors, and angiotensin receptor blockers). Hypokalemia may cause fatal arrhythmias. On the other hand, hyperkalemia may complicate the concomitant treatment with angiotensin II-converting enzyme inhibitor and angiotensin-receptor blockers, $\beta$-blockers, and spironolactone, requiring therapeutic adjustment ${ }^{(16)}$.

According to the Brazilian guidelines on acute heart failure, arterial blood gas analysis should be requested for all patients with severe respiratory distress or signs of low output. The exam enables the analysis of oxygenation $\left(\mathrm{PO}_{2}\right)$ and respiratory function $\left(\mathrm{PCO}_{2}\right)$, as well as acid-base balance $(\mathrm{pH})$ analysis. It should be conducted along with the analysis of lactate, and in case of occurrence of acidosis and hyperlactatemia due to ineffective tissue perfusion a poor prognosis is established to the patient using a VAD as they may be presenting an evolution to cardiogenic shock, even before the development of arterial hypertension. Likewise, retention of $\mathrm{CO}_{2}$ indicates severe respiratory distress ${ }^{(16)}$.

The daily collection and laboratory analysis of total proteins and albumin, as well as the control of bilirubin and liver enzymes, is important in the prevention of HF-related hepatic complications that these samples may offer ${ }^{(18)}$. Cardiac cirrhosis is currently clinically defined by the triad of right-ventricular hepatomegaly, ascites with high protein content, and high albumin gradient between the serum and the ascites fluid. Cardiogenic ischemic hepatitis is characterized by the increased serum level of transaminases and bilirubin after acute and severe fall in cardiac output. Moreover, elevation of liver enzymes may be an indicative of hepatic congestion and/or hypoperfusion ${ }^{(18)}$. The amylase enzyme analysis enables a diagnosis of acute pancreatitis or renal failure, and such complications may lead to clinical hypovolemic shock in individuals that should not be subjected to this risk due to the underlying heart disease, as it happens with patients using a VAD. Regarding the fibrinogen (precursor of fibrin) and the d-dimer (a product of the degradation of fibrin by the plasmin), data on their serum levels may support the diagnosis of diseases and conditions that cause hypercoagulability, and may be useful as a risk marker of deep venous thrombosis and pulmonary thromboembolism in patients presenting cardiovascular alteration ${ }^{(16,18)}$.

The correct identification of microorganisms that cause surgical wound infection by means of the collection of culture is necessary in order to guide the professional behavior in relation to the antibiotic therapy ${ }^{(19)}$.

Antibiotic prophylaxis deserves special attention, because if it is conducted inadequately it will not contribute to prevent the infection and may lead to undesirable effects, including the selection of resistant microbiota, superinfections, and increased incidence of adverse effects to antibiotics ${ }^{(20)}$.

In addition to the care items related to the use of a VAD pointed out in this protocol, other items should be considered in the care of critical patients, including nutritional support and patient pain assessment through facial or visual numeric scales and analgesia $^{(20-21)}$. Prevention of infectious processes should also be a goal to be achieved, especially in relation to patients using mechanical ventilation. Currently, oral hygiene with $0.12 \%$ chlorhexidine is addressed in the literature as an important tool to prevent pulmonary infections ${ }^{(19)}$, as well as the adequate bed positioning and prevention of gastric reflux as a way of preventing pneumonia associated with mechanical ventilation ${ }^{(20)}$.

The protocol content validation was specifically focused on patients using a VAD, covering some items that are not essentially important to be assessed, especially regarding such a complex patient for the standardization of a care plan ${ }^{(22)}$.

The use of protocols, severity scores, and rules may support the care plan and assessment of patients using a VAD. The FAST HUG mnemonic rule developed in 2005 by JL Vincent is indicated for these patients as it covers all their needs by means of a systematized approach to support health professionals, especially those working in intensive care, to assess important aspects in the care of critical patients ${ }^{(23)}$. It is important to mention that all the items with solid evidence of validation in the VAD protocol should be included in the nursing prescription due to its relevance reported in the literature, but further studies of clinical validation will be necessary to verify this hypothesis.

\section{Study limitations}

The present study did not approach themes related to the clinical protocols of anticoagulation and, consequently, of risk of bleeding in which these variables may be studied in a specific protocol.

Contributions for the fields of nursing, health or public policies

Considering the technological advance in the health area that is directly related to the care provided by nursing to patients using ventricular assist devices, the present study may collaborate 
in the implementation and application of a standardized clinical protocol, increasing effectiveness and safety for care practice.

\section{CONCLUSION}

Based on the content validation performed by experts, a protocol containing ten items related to the care of patients using a VAD was developed to guide health professionals in the care of these patients and in the systematization of nursing care, promoting quality care.

Although not contemplated in the protocol, other important care-related items include: adequate nutritional support, patient pain assessment, correct analgesia, and prevention of infectious processes.

\section{REFERENCES}

1. Roger VL, Faha MPH, Turner MB. Heart Disease and Stroke Statistics: 2012 Update. Circulation[Internet]. 2012 [cited 2016 May 9];125(1):e2-e220. Available from: http://www.ncbi.nlm.nih.gov/pmc/articles/PMC4440543/

2. Rahimi K, Duncan M, Pitcher A, Emdin CA, Goldacre MJ. Mortality from heart failure, acute myocardial infarction and other ischaemic heart disease in England and Oxford: a trend study of multiple-cause-coded death certification. J Epidemiol Community Health[Internet]. 2015[cited 2016 Jul 10];69(10):1000-5. Available from: https://www.ncbi.nlm.nih.gov/pmc/articles/ PMC4602272/pdf/jech-2015-205689.pdf

3. Fini A, Cruz DALM. Características da fadiga de pacientes com insuficiência cardíaca: revisão de literatura. Rev Latino-Am Enferm[Internet]. 2009[cited 2016 Jul 10];17(4):557-65. Available from: http://www.scielo.br/pdf/rlae/v17n4/19.pdf

4. Khorsandi M, Shaikhrezai K, Prasad S, Pessotto R, Walker W, Berg G, et al. Advanced mechanical circulatory support for postcardiotomy cardiogenic shock: a 20-year outcome analysis in a non-transplant unit. J Cardiothorac Surg[Internet]. 2016 [cited 2016 Jul 10];11(29):1-13. Available from: https://www.ncbi.nlm.nih.gov/pmc/articles/PMC4758144/pdf/13019_2016_Article_430.pdf

5. Maltais S, Davis ME, Haglund N. Minimally invasive and alternative approaches for long-term LVAD placement: the Vanderbilt strategy. Ann Cardiothorac Surg[Internet]. 2014[cited 2016 Jul 10];3(6):563-9. Available from: https://www.ncbi.nlm.nih.gov/pmc/ articles/PMC4250557/pdf/acs-03-06-563.pdf

6. Miller LW, Guglin M, Rogers J. Cost of ventricular assist devices: can we afford the progress? Circulation[Internet]. 2013[cited 2016 Jul 10];12;127(6):743-8. Available from: http://circ.ahajournals.org/content/127/6/743.long

7. Muller G, Flecher E, Lebreton G, Edouard Luyt C, Trouillet JL, Bréchot N. The ENCOURAGE mortality risk score and analysis of long-term outcomes after VA-ECMO for acute myocardial infarction with cardiogenic shock. Intensive Care Med[Internet]. 2016[cited 2016 Jul 10];42(3):370-8. Available from: http://www.ncbi.nlm.nih.gov/pubmed/26825953

8. Ranjit J, Long JW, Massey HT, Bartley P G, Benjamin C S, Tector AJ, et al. Outcomes of a multicenter trial of the Levitronix CentriMag ventricular assist system for short-term circulatory support. J Thorac Cardiovasc Surg[Internet]. 2011 [cited 2016 Jul 10];141(4):932-9. Available from: http://www.ncbi.nlm.nih.gov/pubmed/20605026

9. Bellucci Jr JA, Matsuda LM. Construção e validação de instrumento para avaliação do Acolhimento com Classificação de Risco. Rev Bras Enferm[Internet]. 2012[cited 2016 Jul 10];65(5):751-7. Available from: http://www.scielo.br/pdf/reben/v65n5/06.pdf

10. Natalio MA, Faria CDCM, Teixeira-Salmela LF, Michaelsen SM. Content validation of a clinical assessment instrument for stair ascent and descent in individuals with hemiparesis. Braz J Phys Ther[Internet]. 2014[cited 2016 July 10];18(4):353-63. Available from: http://www.scielo.br/pdf/rbfis/2014nahead/pt_1413-3555-rbfis-bjpt-rbf-2014-0052.pdf

11. Bucchi SM, Mira VL, Otrenti E, Ciampone MHT. Enfermeiro instrutor no processo de treinamento admissional do enfermeiro em unidade de terapia intensiva. Acta Paul Enferm[Internet]. 2011[cited 2016 Jul 10];24(3):381-7. Available from: http://www.scielo. br/pdf/ape/v24n3/en_12.pdf

12. Shreenivas SS, Rame JE, Jessup M. Mechanical circulatory support as a bridge to transplant or for destination therapy. Curr Heart Fail Rep[Internet]. 2010[cited 2016 Jul 10];7(4):159-66. Available from: https://www.ncbi.nlm.nih.gov/pmc/articles/PMC2970816/ pdf/11897_2010_Article_26.pdf

13. Medeiros ABF, Lopes $\mathrm{CHAF}$, Jorge MSB. Análise da prevenção e tratamento das úlceras por pressão propostos por enfermeiros. Rev Esc Enferm USP[Internet]. 200 [cited 2016 Jul 10];43(1):223-8. Available from: http://www.scielo.br/pdf/reeusp/v43n1/29

14. Pinho CM, Correia RN, Valença MP, Cavalcanti ATA, Gomes ET. Use of the air mattress in the reduction of pressure ulcers: efficacy and perceptions of nursing. Rev Enferm UFPE[Internet]. 2014[cited 2016 Jul 10];8(8):2729-35. Available from: http://www. revista.ufpe.br/revistaenfermagem/index.php/revista/article/viewArticle/5337

15. Nowotny BH, Boner DH, Cnor SM. Ventricular Assist Device Implantation: perioperative nursing considerations 3.5. AORN J[Internet]. 2016[cited 2016 May 15];103(4):389-403. Available from: http://dx.doi.org/10.1016/j.aorn.2016.02.002

16. Bocchi EA, Marcondes-Braga FG, Bacal F, Ferraz AS, Albuquerque D, Rodrigues D. Atualização da diretriz brasileira de insuficiência cardíaca crônica: 2012. Arq Bras Cardiol[Internet]. 2012[cited 2016 Jul 10];98(1Suppl.1):1-33. Available from: http://www. scielo.br/pdf/abc/v98n1s1/v98n1s1a01.pdf 
17. Brasil. Ministério da Saúde. Grupo Hospitalar Conceição/Gerência de Ensino e Pesquisa. Diretrizes Clínicas/Protocolos Assistenciais. Manual Operacional. Porto Alegre: 2008. 11 p.

18. McMurray JJ, Adamopoulos S, Anker SD, Auricchio A, Bohm M, Dickstein K, et al. ESC Guidelines for the diagnosis and treatment of acute and chronic heart failure 2012. Eur Heart J[Internet]. 2012[cited 2016 Jul 10];33:1787-847. Available from: http://onlinelibrary.wiley.com/doi/10.1093/eurjhf/hfs105/full

19. Shi Z, Xie H, Wang P, Zhang Q, Wu Y, Chen E, Ng L, Worthington HV, Needleman I, Furness S. Oral hygiene care for critically ill patients to prevent ventilator-associated pneumonia. Cochrane Database Syst Rev[Internet]. 2013[cited 2016 Jul 10];13;8. Available from: http://onlinelibrary.wiley.com/doi/10.1002/14651858.CD008367.pub3/pdf

20. Eom JS, Lee MS, Chun HK, Choi HJ, Jung SY, Kim YS, Yoon SJ, Kwak YG, Oh GB, Jeon MH, Park SY, Koo HS, Ju YS, Lee JS. The impact of a ventilator bundle on preventing ventilator-associated pneumonia: a multicenter study. Am J Infect Control[Internet]. 2014[cited 2016 Jul 10];42(1):34-7. Available from: http://www.ncbi.nlm.nih.gov/pubmed/24189326

21. Schmidt M, Stewart C, Bailey M, Nieszkowska A, Kelly J, Murphy L, et al. Mechanical ventilation management during extracorporeal membrane oxygenation for acute respiratory distress syndrome: a retrospective international multicenter study. Crit Care Med[Internet]. 2015[cited 2016 Jul 10];43(3):654-64. Available from: http://www.ncbi.nlm.nih.gov/pubmed/25565460

22. Cuzco CC, Guasch PN. Application and evaluation of care plan for patients admitted to Intensive Care Units. Enferm Intensiva[Internet]. 2015[cited 2016 Jul 10];26(4):137-43. Available from: http://www.ncbi.nlm.nih.gov/pubmed/26340906

23. Vincent JL. Give your patient a fast hug (at least) once a day. Critical Care Med[Internet]. 2005[cited 2016 May 9];33(6):1225-9. Available from: http://www.ncbi.nlm.nih.gov/pubmed/15942334 